\title{
Babinski's contributions to cerebellar symptomatology: building the basis of the neurological examination
}

\author{
As contribuições de Babinski para os sinais cerebelares: construindo as \\ bases do exame neurológico
}

José Luiz Pedroso', Orlando G. P. Barsottini', Christopher G. Goetz²

\begin{abstract}
Several assumptions about the function of the cerebellum and semiotic signs have been described over the centuries. Among the long list of famous researchers who have provided a strong contribution and who have left their names on the highway of cerebellar research, Joseph Babinski appears as a prominent name. The description of various forms of cerebellar symptomatology was a major part of Babinski's work, and clinical terms that he introduced, namely hypermetry, diadochokinesia, and asynergy, remain part of contemporary clinical vocabulary. Babinski studied cerebellar signs in many patients and was able to conduct longitudinal studies that permitted him to understand the evolution of cerebellar dysfunction. Babinski contributions to cerebellar symptomatology continue to influence the most modern theories, including functional and neuropathological studies.
\end{abstract}

Keywords: cerebellum, cerebellar signs, Joseph Babinski, hypermetry, diadochokinesia, asynergy.

\section{RESUMO}

Diversas teorias sobre a função do cerebelo e a semiologia dos sinais cerebelares têm sido descritas ao longo dos séculos. Dentre a longa lista de pesquisadores renomados que apresentaram importantes contribuições nesse assunto e que deixaram seus nomes na história, Joseph Babinski aparece com destaque. A descrição dos mais variados sintomas e sinais cerebelares foi peça importante do trabalho de Babinski e algumas nomenclaturas introduzidas por ele, tais como hipermetria, disdiadococinesia e assinergia, continuam a fazer parte do vocabulário contemporâneo. Babinski estudou os sinais cerebelares em muitos pacientes e foi capaz de realizar pesquisas que lhe permitiram compreender a disfunção cerebelar. As contribuições de Babinski para a caracterizar a sintomatologia cerebelar continuam a influenciar as teorias mais modernas, a despeito de estudos funcionais e neuropatológicos.

Palavras-chave: cerebelo, sinais cerebelares, Joseph Babinski, hipermetria, disdiadococinesia, assinergia.

The structure and function of the cerebellum has been the focus of study over many centuries. Works of early pioneers still exert important influences on the way we approach the neurological examination. Theories on anatomoclinical correlation continue to influence the most modern theories, even after the advent of functional imaging ${ }^{1}$. Among the long list of famous researchers who have strongly contributed, Joseph Babinski is particularly prominent ${ }^{1-3}$.

\footnotetext{
'MD, PhD; Departamento de Neurologia e Neurocirurgia, Setor de Neurologia Geral e Ataxias, Universidade Federal de São Paulo, Sao Paulo SP, Brazil; 2MD; Department of Neurological Sciences, Rush University Medical Center, Chicago, Illinois, USA.

Correspondence: José Luiz Pedroso; Departamento de Neurologia / Universidade Federal de São Paulo; Rua Botucatu 8, 740; 04023-900 São Paulo SP Brasil; E-mail: jlpedroso.neuro@gmail.com

Conflict of interest: There is no conflict of interest to declare.

Financial disclosures: José Luiz Pedroso, MD, and Orlando G. P. Barsottini, MD, have nothing to disclose.

Financial disclosures:

Christopher G. Goetz, MD [Jan 2013] Disclosures for the past 12 months: Consulting and Advisory Board Membership with honoraria: AOP Orphan, Addex Pharma, Advanced Studies of Medicine, Boston Scientific, CHDI, Health Advances, ICON Clinical Research, Ingenix (i3 Research), National Institutes of Health, Neurocrine, Oxford Biomedica, Synthonics. Grants/Research: Funding from NIH, Michael J. Fox Foundation, NIH. Dr. Goetz directs the Rush Parkinson's Disease Research Center that receives support from the Parkinson's Disease Foundation. He directs the translation program for the MDS-UPDRS and UDysRS and receives funds from the MDS for this effort. Honoraria: Movement Disorder Society, American Academy of Neurology, Movement Disorder Society, University of Pennsylvania, University of Chicago, University of Luxembourg. Intellectual Property Rights: none.

Ownership interests: none. Royalties: Oxford University Press, Elsevier Publishers, Wolters Kluwer Health- Lippincott, Wilkins and Williams. Salary: Rush University Medical Center.

Received 15 May 2013; Received in final form 19 June 2013; Accepted 26 June 2013.
} 
Joseph Jules François Félix Babinski was a famous French neurologist of Polish descent. He is best known for his description of the Babinski sign, a pathological plantar reflex suggestive of corticospinal tract impairment. Babinski received his medical degree from the University of Paris in 1884. He came early to Professor Jean-Martin Charcot at Paris' Salpêtrière Hospital and became his favorite student. Babinski was a masterful clinician, minimally dependent on neuropathological examinations and laboratory tests. Although he advanced rapidly under Charcot's tutelage, after Charcot's death, Babinski was marginalized, and he never attained a high academic position in the French medical hierarchy. Free of teaching duties allied to professorship, he worked at the Hôspital de la Pitié next door to the Salpêtrière and focused on clinical neurology $y^{4,5}$.

The Babinski sign is the most widely appreciated and globally entrenched eponym in Neurology. In 1896, Joseph Babinski described this primitive reflex in a 28-line communication. A remarkable characteristic of Joseph Babinski was that he painstakingly examined patients with neurological diseases, and his techniques helped to create the method of the neurological examination that remains the basis of contemporary neurological practice worldwide. While Charcot used the "contemplative method" by watching patients silently for hours with scrupulous attention and focusing on the neurological history in arriving at diagnoses, Babinski and other younger neurologists of his generation built the neurological examination as it is today ${ }^{4,6}$.

In addition to his fundamental departure from Charcot's conception of hysteria, Babinski devoted himself to three main tasks: the development of cerebellat semiology, the study of tendon reflexes, and the identification of new neurological treatments for his patients. This essay focuses on his work concerning the cerebellum.

Babinski had previously studied the work of the early researchers on the cerebellum, and was aware of Rolando's work from two centuries earlier, showing that cerebellar lesions impair movement coordination. Further, he was aware that galvanic stimulation of the cerebellum increased movement. The description of various forms of cerebellar symptomatology was a major part of Babinski`s work, and clinical terms that he introduced, namely hypermetry, diadochokinesia, and asynergy, remain part of contemporary clinical vocabulary ${ }^{1,7}$. He studied cerebellar signs in many patients and was able to conduct longitudinal studies that permitted him to understand the evolution of cerebellar dysfunction. One of the patients particularly studied by Babinski, Henri Mouninou (Figure), was followed clinically for more than twenty years, finally documenting cerebellar necrotic lesions of vascular origin at autopsy.

The first paper from Babinski on cerebellar symptomatology was published in 1899, and concerned the description of asynergy. Corporal movements, such as standing up,

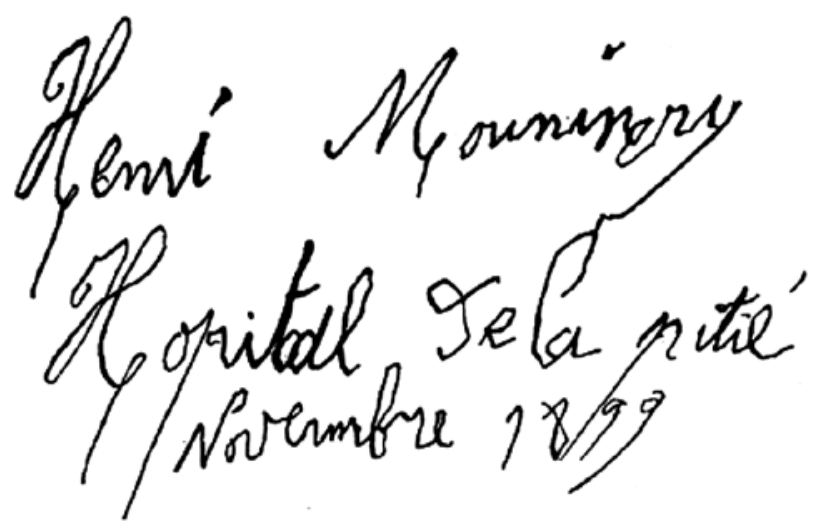

Figure. Handwriting of Mouninou, the Babinski patient with cerebellar symptoms. This figure is used with permission from Dr. Jacques Poirier, one of the authors of the book entitled "Joseph Babinski: a Biography". By permission of Oxford University Press, USA (URL www.oup.com ).

walking, and carrying out voluntary movements to command required good coordination among paired groups of agonist and antagonist muscles. Babinski considered that this coordinated function, involving timed muscular coordination, is controlled by the cerebellum. Asynergy, as Babinski named it, is the disorder of this function, where muscular strength was preserved, but the coordinated integration of timed movements was disrupted. He described several techniques that demonstrated this phenomenon during the neurological examination ${ }^{4,8}$.

In 1902, Babinski further described the disordered timing of volitional movements in patients with cerebellar lesions. The term adiadochokinesia was firstly proposed by Bruns, and referred to the impossibility of executing a rapid succession of elementary movements, such as placing the hands alternately pronated or supinated. Babinski preferred the word diadochokinesia, stating that "the cerebellar lesions are able in a way, without diminishing muscular strength, to create an inertia seen in the difficulty of starting the movement and stopping it in time" 2,4 .

In a synthesis of his work on the cerebellum in 1913, Babinski also included the term hypermetry. The techniques that Babinski described to demonstrate hypermetry are still part of our routine exam. On his own words, to test hypermetry, "the patient is asked to put his index finger at the tip of his nose... the patient with cerebellar disorder, does not stop, but goes beyond, and the finger collides violently with the nose and from there makes its way outside the target, toward the cheek and ear". As for testing hypermetry, Babinski highlighted two essential points: firstly, the patient must perform these movements rapidly; second, contrary to what was observed in posterior column syndromes, there is no aggravation of the disorder when the eyes are occluded. This important distinction helped to separate pure cerebellar syndromes from the much more common locomotor ataxia or 
tabes dorsalis. Babinski presented the important concept of the cerebellum as an inhibitory check on excessive motor function, stating "the cerebellum is a regulator of movement, acting mainly as a break"4.

Some of his terminology was not widely adopted. The term cerebellar catalepsy was created by Babinski to characterize the power of muscles, in the state of voluntary contraction, to stay still in certain positions for a long time "as if they were rigid, without however being in spasm" 4 . According to Babinski, this phenomenon is best demonstrated with the patient lying in bed with the thighs flexed and separated. In spite of instability during standing, the legs can remain still and steady in this recumbent position, showing the particular position sensitivity of instability in cerebellar lesions.

Babinski lived to see his achievements in neurology internationally acclaimed, although his contributions were less acknowledged in France itself. He was honored by Poland's Wilno University, by the American Neurological Society, and by other foreign societies. In 1913, Babinski received a standing ovation at the Seventeenth International Congress in London for his work on the cerebellum ${ }^{4}$. In spite of world acclaim, he was by-passed in the French academic hierarchy and never received the title of Associate Professor (agregé) or Professor. Babinski died in Paris on 13 December $1932^{4}$.

\section{References}

1. Manto M. The cerebellum, cerebellar disorders, and cerebellar research--two centuries of discoveries. Cerebellum 2008;7:505-516.

2. Babinski J. Sur le rôle du cervelet dans les actes volitionnels nécessitant une succession rapide de mouvements (diadococinésie). Rev Neurol 1902;10:1013-1015.

3. Glickstein M, Strata P, Voogd J. Cerebellum: history. Neuroscience 2009;162:549-559.

4. Philippon J, Poirier J. Joseph Babinski: a Biography. Oxford University Press, New York, 2009.
5. Goetz CG, Bonduelle M, Gelfand T. Charcot: constructing neurology. Oxford University Press, New York, 1996.

6. Clarac F, Massion J, Smith AM. Duchenne, Charcot and Babinski, three neurologists of La Salpetrière Hospital, and their contribution to concepts of the central organization of motor synergy. J Physiol Paris 2009;103:361-376.

7. Fine EJ, Ionita CC, Lohr L. The history of the development of the cerebellar examination. Semin Neurol 2002;22:375-384.

8. Babinski J. De l'asynergie cérébelleuse. Rev Neurol 1899;7:806-816. 